\title{
The Role of Mindful Organising in Relation to Innovation Adoption of Employees in Logistics
}

Peter OeiJ

TNO, The Netherlands Organisation for Applied Scientific Research Schipholweg 77-89, 2316 ZL, Leiden, The Netherlands

Corresponding author: peter.oeij@tno.nl

Katarina Putnik

TNO, The Netherlands Organisation for Applied Scientific Research Schipholweg 77-89, 2316 ZL, Leiden, The Netherlands

Email: katarinaputnik@yahoo.com

Steven Dhondt

TNO, The Netherlands Organisation for Applied Scientific Research

Schipholweg 77-89, 2316 ZL, Leiden, The Netherlands; and K.U. Leuven, Belgium

Email: steven.dhondt@tno.nl

WOUTER VAN DER TORRE

TNO, The Netherlands Organisation for Applied Scientific Research Schipholweg 77-89, 2316 ZL, Leiden, The Netherlands

Email: wouter.vandertorre@tno.nl

Paul Preenen

TNO, The Netherlands Organisation for Applied Scientific Research Schipholweg 77-89, 2316 ZL, Leiden, The Netherlands

Email: paul.preenen@tno.nl

ERnest De VRoOme

TNO, The Netherlands Organisation for Applied Scientific Research Schipholweg 77-89, 2316 ZL, Leiden, The Netherlands

Email: ernest.devroome@tno.nl 


\section{About the authors}

Peter R.A. Oeij (Ph.D.) is senior research scientist, consultant and project manager at TNO, a Research and Technology Organisation in the Netherlands employing almost 3.000 staff members. His field of interest covers innovation management, workplace innovation, social innovation, and team dynamics. Peter received his Ph.D. in management science from the Open University of the Netherlands. He obtained master degrees in history, sociology (both at Erasmus University Rotterdam) and psychology (Open University). Currently, he is the project coordinator of BEYOND4.0, a EU-Horizon2020 research project about the economic and social consequences of the digital transformation in six EU-regions (wWw.beyond4-U.eu), and participated in SI-DRIVE, another EU-project about driving forces of social innovation (wWw.si-drive.eu).

Katarina Putnik (Ph.D.) was a quantitative and qualitative researcher at TNO during this study, with a background in psychology and social medicine. Her drive is to contribute to the development of healthy and successful organisations by focusing on their innovation and diversity. She receives high evaluation from people cooperating with her and sees the impact of joint work in scientific as well as practitioners' world. Since 2019 she has been working as a senior policy advisor at Erasmus University Rotterdam, focusing on issues of diversity and inclusion among employees.

Steven Dhondt (Prof., Ph.D.) is a professor at the KU Leuven (Belgium) and a senior research scientist at TNO. His main focus is on the impacts of the newest technologies on organisational and work practices. He coordinates at TNO with the "Smart Working" research programme on the impacts of robotics and digitization on organisational practices. He has been the coordinator of the European Workplace Innovation Network (EUWIN) and is the scientific coordinator of the H2020 Beyond4.0 and the Belgian SBO Paradigms4.0 projects.

Wouter van der Torre (MSc) is a researcher and project manager at TNO since 2010. His expertise includes workplace innovation, employability, lifelong learning, and the impact of technology on work. He has successfully led research projects for national as well as international clients in the private and public sectors. Currently, Wouter is the program manager of the research program "Future of Work" and the project manager of a national survey about the sustainable employability and working conditions of self-employed persons in the Netherlands (ZEA).

Paul Preenen (Ph.D.) is a senior researcher at TNO and holds a PhD in Organizational Psychology. His research focuses on organizational behaviour, and consequences of technological innovations for labour, organisations, and employees. His work has been published in international academic and professional journals, and has been discussed in (inter)national media. Paul's key strength is to create impact by translating top scientific research into practical knowledge.

Ernest de Vroome (Ph.D.), has been working at TNO 'Work, Health Technology' since 1999 as a researcher, epidemiologist and statistician primarily on the subject of the reciprocal relationships between 'work' and mental and physical health. He is responsible for the management and analysis of the TNO monitoring program, in which the National Employer Survey (the 'WEA') used in this paper plays an important role.

Journal of Management and Training for Industries, Vol.7, No.2, 2020 


\section{Abstract}

Many innovations do not get implemented. This study examines the innovation adoption of employees as one of the factors responsible for unsuccessful implementation. The assumption is that mindful organising positively associates with innovation adoption. The study looks into the role of mindful organising of employees, which includes resilience, as well as organisational and individual characteristics about innovation adoption, i.e., the actual use of innovation by employees. Managers of 110 Dutch organisations from the transport and logistics sector took part in a survey and were required to evaluate the behaviour of the employees they are supervising. The dependent variable is the actual use of innovation, the indicator of innovation adoption. Independent variables are mindful organising, workplace innovation, supportive leadership, and perception of innovation (perceived usefulness, perceived ease of use, and subjective norm). The data was analysed using multiple regression (path analysis). Workplace innovation, voice and perceived ease of use have a direct relation with the actual use of innovation by employees (i.e., successful innovation adoption). Mindful organising is related to all aspects of perception of innovation: perceived ease of use, perceived usefulness and subjective norm, i.e., the influence of other important factors (e.g., managers and co-workers). Mindful organising has an indirect influence on the actual use of innovation via perceived ease of use of innovation. Supportive leadership has a relation with perceived usefulness and subjective norm, and an indirect influence on the actual use of innovation via perceived usefulness. The conclusion is drawn that mindful organising (including resilience), workplace innovation, perceived usefulness and perceived ease of use associate with innovation adoption. The practical implication is that management needs to ensure there is an environment that fosters mindful organising and gives employees sufficient room to express their opinion in the team in the process of renewal. Apart from mindful organising, attention to workplace innovation is significant for innovation adoption.

Keywords: Innovation Adoption, Logistics, Transport, Mindful Organising, Resilience, Workplace Innovation

\section{Introduction}

These days innovation is paramount for organisations to survive or stay at the forefront of their businesses. Organisations face several problems in being innovative, which have to do with financing, expertise and knowledge, entrepreneurship, luck, and having the right personnel, to mention just a few. One of the highly innovative industrial sectors in the Netherlands is logistics. However, even in this branch, innovations available to companies seem to be underused, due to traditional HR policies, which may hinder the uptake of renewal (Manpower Group, 2015). What fosters the adoption of innovation by employees?

This article reports a study of innovation adoption in the logistics sector in the Netherlands. The Netherlands scored high on the European Commission's EU Transport Scoreboard and in the Logistics Performance Index for many years. As an international hub in the sphere of logistics, its excellent knowledge 
infrastructure and the presence of the 'main port' Schiphol and the port of Rotterdam give the country its international top position and make it perform very efficient in relation to congestion issues, high costs and regulatory burdens ("Top sector logistics", 2020 ). However, competition is fierce, profits are very marginal, and the need to continuously innovate is severe. The working population of logistics is aging at the same time, and the company cultures are depicted as 'traditional'. Moreover, many firms are rather small and many innovations are not taken up by the sector and deploying personnel in this process seems underused (Manpower Group, 2015). For this reason, the logistics and transport branch wants to know how the uptake of innovation could be given a boost by better engaging the employees in the process of absorbing knowledge from the outside, the implementation of renewal, and introducing new technologies and innovation. The research offers an opportunity to investigate innovation adoption in this aspect and its relations with concepts such as mindful organising, workplace innovation and leadership. This study is an exploration of such relationships and a stepping stone for further theory building.

The article is organised as follows. We start with a discussion of the relevant literature to study innovation adoption related to individual behaviour and the organisational context in which employees might agree to work with innovations. It is followed by the construction of a conceptual model that intends to help explain the innovation adoption of employees. In the next section, we discuss the research and the method, where we present research questions, hypotheses, the variables and the data. Then we show the analyses and the results in the subsequent section, and conclude our article with a final section with limitations and recommendations included. Figure 1 illustrates our 3-step research process; namely literature review and research design (step 1), fieldwork and analysis (step 2) and analysis results, conclusions, limitations and

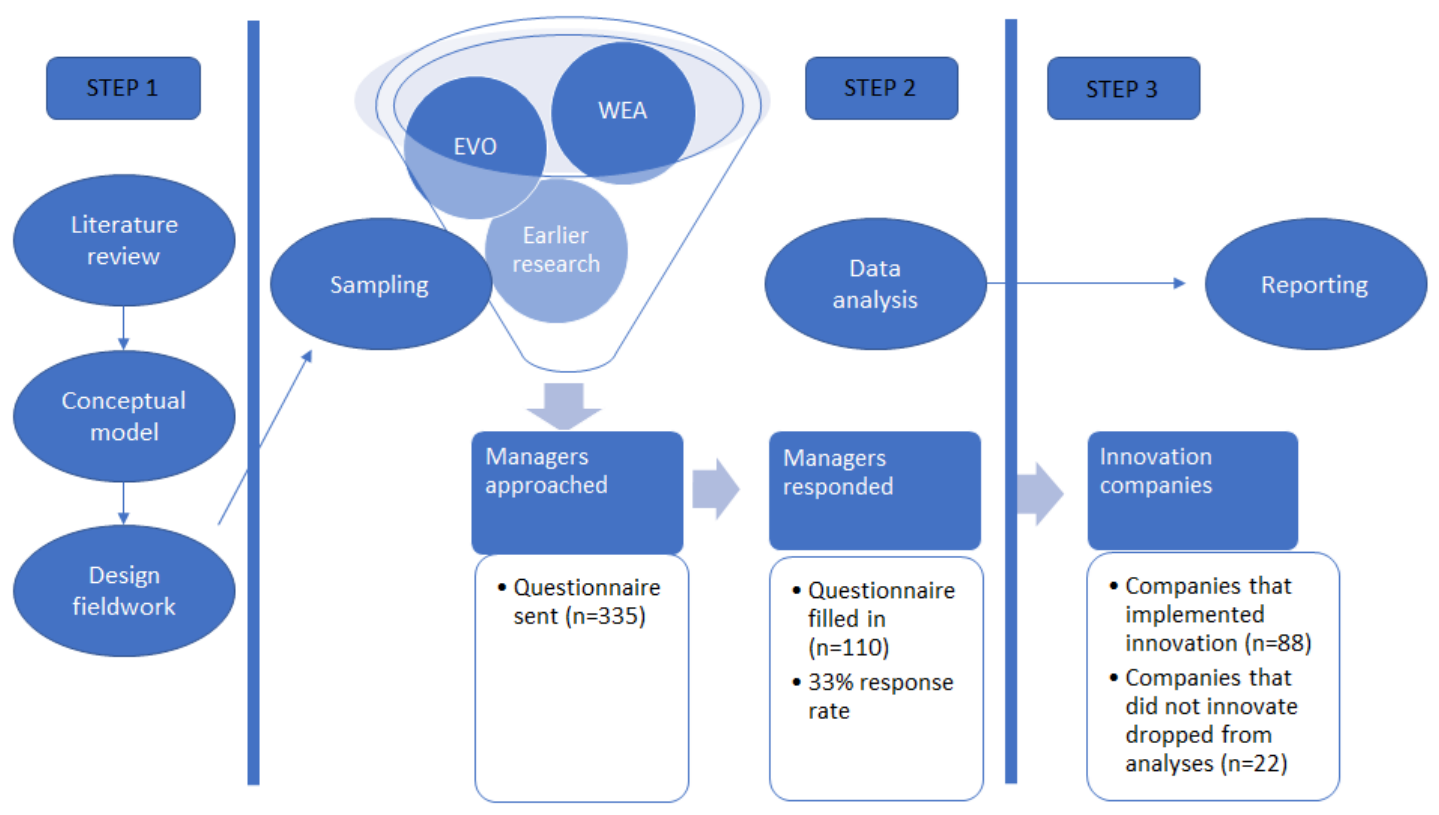

Fig. 1 Research Process 
future research and implications (step 3).

\section{Literature and Theoretical Aspects}

In this section, we will be discussing the theoretical background of our study. The primary literature regarding this topic will be reviewed in order to build a conceptual model for innovation adoption in relation to mindful organising. The theoretical aspects will then be combined into a model, which we will use to test the various relations. Innovation adoption will be connected to the theories that explain why an individual wants to work with innovation, such as new technology. Such theories take the perception of innovation as a point of departure and integrate staffs' attitudes and motivations into their explanatory model. In addition to such a person-centred approach we acknowledge that employees do not live in a vacuum, as they are surrounded by environmental aspects. It is, therefore, of importance how they perceive their organisational contexts, such as the presence of workplace innovation, supportive leadership and mindful organising. In this study, we aim to relate the perception of organisational contexts with the perception of innovation by the employees.

\section{Review of the main aspects of innovation adoption}

Adoption is the decision to proceed with the implementation of practice - here agreeing to work with an innovation (Wisdom, et al., 2014). Innovation adoption can be improved when potential users perceive it as useful, easy to work with, and beneficial for their work performance (Bagozzi et al., 1992; Davis, 1989; Mun et al., 2006; Rogers, 2003; Venkatesh and Davis, 2000; Venkatesh et al., 2003). Several behavioural theories inform us about innovation and the role of employees. Some theories focus on technological aspects of the innovations, such as the Technology Acceptance Theory (Davis, 1989; Bagozzi et al., 1992, Mun et al., 2006), while others more on individual aspects of behaviour and possibilities to change this behaviour, like the Theory of Planned Behaviour (Ajzen, 1991, 2012; Fishbein and Ajzen, 2010) and the Innovation Diffusion Theory (Rogers, 2003). In theoretical models like these, innovation adoption is often operationalised as 'the actual use of innovation?

Realising and implementing innovation is not easy. Many studies report high failure rates, some even as high as seventy to ninety percent, although it is more likely that those rates are lower, say Castellion and Markham (2013). A persistent myth in product innovation and management is that the failure rate of new products is $80 \%$ or higher, whereas the conclusions of empirical studies since 1977 state that the new product failure rate is $40 \%$ or less (Castellion and Markham, 2013). However, $40 \%$ is still substantial, and worth bringing down.

Innovation adoption (Wisdom et al., 2014), measured as the actual use of innovation by employees, is likely to be hampered when employees experience a working environment which is psychologically unsafe and lacks supportive leadership, and where employees have limited team voice and job autonomy (Oeij et al., 2018). Several theoretical frameworks have examined the innovation process in the past. The Technology Acceptance Theory (Davis, 1989; Bagozzi et al., 1992; Mun et al., 2006; Taherdoost, 2018) indicates that the technical aspects of the innovations determine their acceptance, while the Theory of planned behaviour 
(Ajzen, 1991; Fishbein and Ajzen, 2010; Venkatesh and Davis, 2000; Tornikoski \& Maalaoui, 2019) looks at the motivation of the users to change their behaviour and accept renewal. A substantial number of innovation implementations fail to get adopted. We assume that the presence of mindful organising enhances the uptake of innovations by employees, as this suppresses the inclination to avoid risk-taking and strengthens the capability to respond resiliently to disappointment and mishaps (Oeij, 2017, 2018).

Mindful organising is a concept stemming from safety and crisis management organisations to prevent disasters and failure but has hardly been applied to the context of innovation. The concept includes being alert to weak signals for failure and to base behaviour and decisions on evidence and facts, and at the same time being able to recover from mishaps and change of directions resiliently. High-reliability Organisations, such as nuclear power plants and aircraft carriers, excel in mindful organising (Weick and Sutcliffe, 2007), but how about organisations that implement innovation, such as in the logistics sector? Can mindful organising help those companies to fulfil their task more successfully, and thus reduce the risks of failure?

From the viewpoint of organisational behaviour and team dynamics, it is known that workplace innovation, job autonomy, team voice and leadership positively associate with acceptance of innovation, innovative behaviour and successful implementation of innovation (Edmondson, 2012; Hoegl \& Gemuenden, 2001; Hūlsheger et al., 2009; Kremer et al, 2019; Sarros et al., 2008; Yukl, 2012).

Workplace innovation is a way of engaging employees in the process of innovation, such as in developing innovation and by facilitating the cooperative role of employees by adapting to the organisation and jobs. Workplace innovation measures enabled embedment of new technologies and the adoption of renewal by employees. Such measures often have a simultaneous effect of improving organisational performance and the work quality of employees. Putnik et al. (2019a) showed that workplace innovation has a direct effect on the adoption of innovations by employees in logistic firms. A study of 50 companies across Europe provided concrete examples of cooperation between management and employees targeted at renewal and change in the realm of workplace innovation, which resulted in better organisational performance and highly involved, satisfied employees (Oeij et al., 2016).

Job autonomy refers to the fact that employees can determine how they carry out their work to a certain degree (Karasek and Theorell, 1990; Kraan et al., 2000). Some recent studies confirm the importance of job autonomy for innovation and innovative behaviour. De Spiegelaere et al. (2014) found a positive relation between job autonomy and innovative work behaviour. Burcharth et al. (2017) recorded positive associations between employee autonomy and open innovation. In another example, Giebels et al. (2016) reported that job autonomy indirectly supports innovative employee behaviour. Finally, Theurer et al. (2018) found that autonomy dimensions (work scheduling autonomy, work methods autonomy, decision-making autonomy) have a significant direct effect on employees' perceived innovative work behaviour.

Team voice indicates whether employees feel free to express themselves and are committed to the organisation (LePine and Van Dyne, 2001). Recently, Ye et al. (2019) observed that team voice mediates the relationship between inclusive leadership and team innovation, and the performance pressure moderates the direct relationship as well as the indirect relationship between inclusive leadership and team voice via team voice. Such relationships tends to be stronger when performance pressure is high. Kremer et al. (2019) sug- 
gested that critical factors that serve as antecedents of innovation and include employee voice and knowledge sharing, in turn, lead to creativity and innovation. A study by Oeij (2018) showed that innovation teams have better results when the team voice is present. Team voice breeds employee engagement, which helps the implementation of innovation, renewal and change (Oeij et al., 2015).

Leadership can be seen as guiding and structuring the work of employees to achieve organisational goals. Innovations leaders are change agents who promote the manifestation of new ideas in a work context by creating a supportive climate for creativity and managing the innovation process (Kremer et al., 2019; Rogers, 2003). Leadership styles vary, however. For example, transformational leadership, in particular, is found to be very important for stimulating the innovative behaviour of employees (Nusair et al., 2012). Supportive leadership influences the working environment of employees. It can create psychological safety and learning orientation (Edmondson, 2012), voice (LePine and van Dyne, 2001), and both organisational and mental support (Kremer et al., 2019).

A relatively new approach is to study mindful organising, also called organisational mindfulness and collective mindfulness in relation to innovation (Brummans, 2017, Tolk et al., 2015; Weick and Sutcliffe, 2015). Unknown is whether mindful organising can help logistics companies to more successfully implement innovation. Sullivan and Yang (2016) studied the differentiated impact of organisational mindfulness (operationalised as organisational attention and learning) on different types of firm innovation, and contended that organisational mindfulness associates with innovations. While organisational mindfulness has a positive relationship with innovation with a lower degree of novelty, there exists an inverse U-shaped relationship between organisational mindfulness and firm innovations with a higher degree of novelty. Oliver et al. (2016) found strong and significant relationships between collective mindfulness, measured by the 'Mindful Organizing Scale' (Weick and Sutcliffe, 2015) and objective measures of performance, particularly when the teams are pursuing ambitious, high-risk strategies. Elbanna and Murray (2009) studied an appreciative inquiry of a successful IS project (Information Systems), which delivered an innovative business solution that was highly appreciated and valued by the business. Analysis of post-project data reveals the resemblance of the project practices with the creation of collective mindfulness, which offers the organisation the opportunity to create a 'bubble' of collective mindfulness. This bubble of collective mindfulness has the capacity to sustain a high level of vigilance and sensitivity to business operations and needs, which fosters business innovation and the delivery of a successful solution. In earlier research, Vogus and Welbourne (2003) reported suggestive evidence that organisational mindfulness is associated with a greater number of patents as an indicator of innovation. A meta-review of resilience, which is an element of organisational mindfulness, showed that higher alertness and resilience make teams more effective and efficient, and avoid mistakes (Alliger et al., 2015). Finally, Oeij's study of innovation teams (2018) suggested that organisational mindfulness enables resilient team behaviour in solving critical incidents and thus achieves better project results.

\section{Construction of a conceptual model}

Based on this organisational behaviour and the team-dynamics viewpoint, a research model was developed that pays attention to both individual behaviour characteristics and organisational behaviour characteristics. 
The individual behaviour builds on the theories of planned behaviour and technology acceptance, while the organisational behaviour encapsulated workplace innovation (incorporating job autonomy and team voice), leadership and organisational mindfulness.

The Theory of Planned Behaviour (Ajzen, 1991; Fishbein and Ajzen, 2010) states that individual behaviour is preceded by behavioural intentions. A person's individual motivation determines one's attitudes, perceptions of influential others and self-assurance to perform well. The theory of Fishbein and Ajzen operationalises these factors as behavioural attitudes, subjective norms and self-efficacy, respectively. It is a general behavioural theory that needs to make the context specific. In our case, under the context of employees adopting innovations, a theory that meets such needs is the Technology acceptance theory. According to this theory, the intention to adopt a new technology or an innovation is driven by the perceived usefulness of an innovation (benefit) and its perceived easiness in use (user-friendliness) (Bagozzi et al., 1992; Davis, 1989, Mun et al., 2006). Perceived usefulness refers to the expectation that innovation will improve one's performance. This is possible when the individual evaluates the new technology as relevant to the performer's output (quality judgment), and recognizes the suitability to apply the new technology to specific tasks (relevance). A potential user needs to expect that applying the new technology is indeed successful (result demonstrability), for example, by watching others using it (Rogers, 2003; Venkatesh and Davis, 2000). Perceived easiness is associated with a person's perceived self-efficacy to apply the new technology successfully. Finally, subjective norms (for example, opinions of managers about the importance of innovation) determine the intention to apply and adopt innovations (Ajzen, 1991; Fishbein and Ajzen, 2010; Venkatesh et al., 2003; Venkatesh and Davis, 2000).

The individual behavioural characteristics are directly linked to innovation adoption, i.e., the actual use of an innovation. Organisational behavioural characteristics are favourable conditions that enable 'the mechanism of planned behaviour of technology acceptance' to be set in motion and to support it.

Job autonomy (Karasek and Theorell, 1990) is the decision latitude according to which persons select and execute tasks. The level of autonomy is equivalent to a certain degree of professional freedom and mastery. High job autonomy often implies that employees can choose controllable workload levels and create learning opportunities (Karasek and Theorell, 1990; De Sitter et al., 1997). Job autonomy influences a person's organisational behaviour repertoire and room to maneuver. It enlarges one's behavioural options, thus intentions.

Job autonomy is an element of job and work design and is inextricably linked to the voice persons get. Voice determines the working environment and creates the conditions to raise one's voice if needed. The presence of employee voice implicitly determines a psychologically safe surrounding that allows making mistakes and prevents punishment (De Dreu, 2002; Edmondson, 2012). Adopting innovation requires people to feel invited to express their opinions.

Since there is a theoretical overlap among the concepts of workplace innovation and job autonomy and team voice, we operationalise workplace innovation via autonomy and team voice. For that purpose, we constructed a new variable 'workplace innovation' in an earlier analysis (Putnik et al., 2019a) that we will use in the present conceptual model.

Journal of Management and Training for Industries, Vol.7, No.2, 2020 


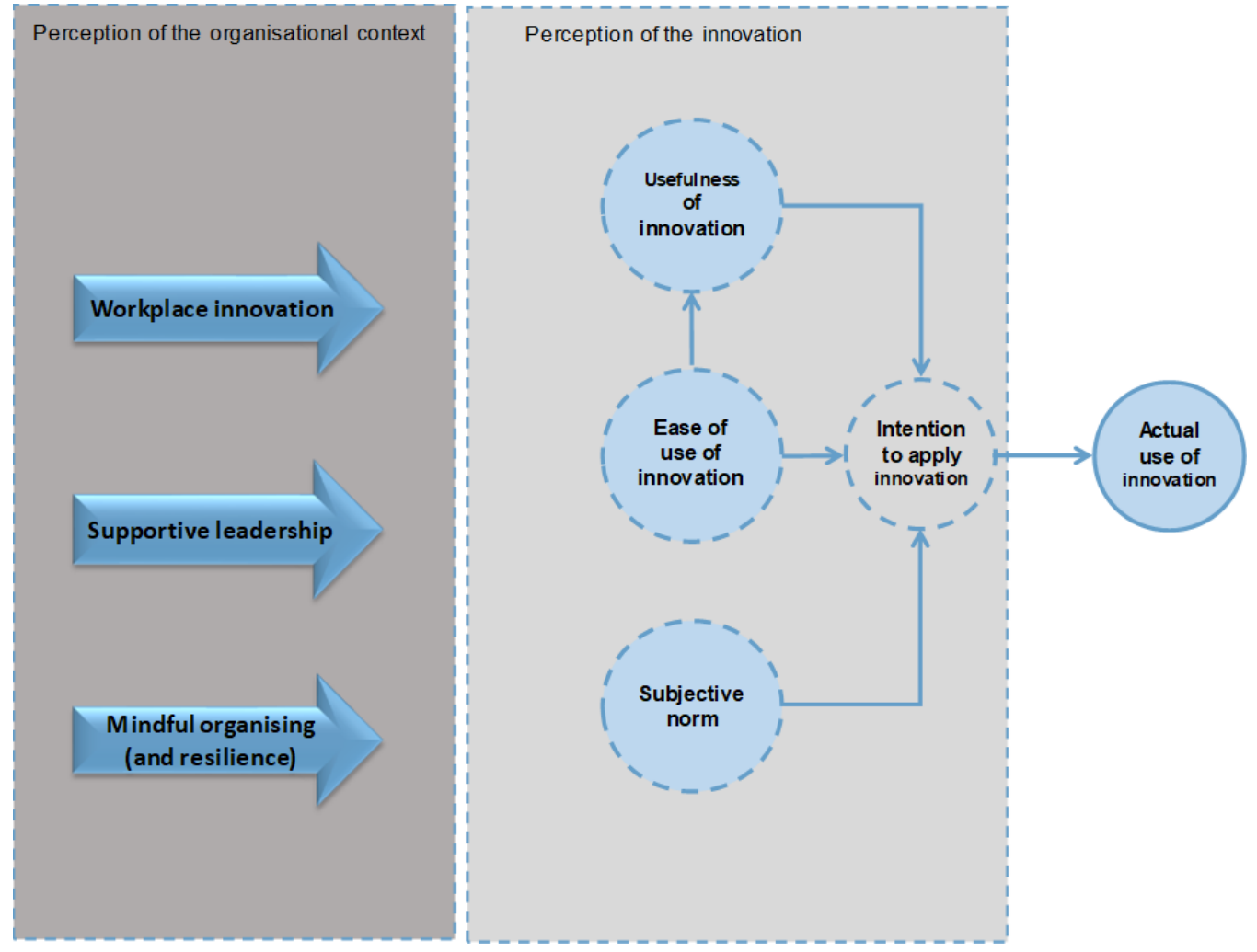

Fig. 2 Conceptual Model of Innovation Adoption of Employees

Workplace innovation, job autonomy and team voice are elements of an organisational context by design, and so is leadership behaviour, to a large extent. The design of an organisation can be more or less centralised, depending on the present management philosophy, and will affect how people behave. The more decentralised, the more autonomy, team voice and supportive leadership can be expected (Karanika-Murray and Oeij, 2017). For individual behavioural intentions, it matters how employees perceive the leadership of their managers. For employees to adopt innovation, leadership should engage, stimulate and support others, and rule out possible ambiguity, to which the introduction of newness is conducive (Totterdill and Exton, 2017). Leadership should be synergetic and able to deal with conflicting goals (Lawrence et al., 2009). If successful, such leadership will be an example for employees, and determine the subjective norm to which innovation is relevant.

Even if the working environment is well-equipped with workplace innovation (including job autonomy and team voice) and supportive leadership, innovation may fail to become adopted. Several reasons may play a role, such as lacking financial resources, changing scopes, technological setbacks and personnel fluidity. Organisational mindfulness could be a barrier against critical incidents that may cause the failure of innovation adoption. Collective mindfulness in organisations (Sutcliffe, Vogus and Dane, 2016) is defined as the collective capability to discern discriminatory detail about emerging issues and to act swiftly in response to these details (Weick et al., 1999). In other words, collective mindfulness - or organisational mindfulness 
or mindful organising - is about being alert and being resilient. Resilience is the ability of persons to bounce back from mishaps and maintain an operational course in such a way that performance remains reliable and productive (Weick and Sutcliffe, 2015). Resilience can be helpful to adopt innovation eventually. If team members and employees are working in an environment that can be characterised as organisationally mindful, they are expected to show less resistance against innovation. In that case, they have a collective consciousness or 'mindset' that helps them to deal with setbacks, and new things that seem difficult to handle or to learn (De Clercq, 2019; Hartmann et al., 2019; Todt, Weiss \& Hoegl, 2019).

From this discussion a conceptual model was derived that we used for the research (Figure 2). The picture suggests that the way employees perceive the organisational context determines how they will perceive the innovation, and actually take up the innovation or not, i.e., whether the actual innovation adoption will take place.

\section{Research and Method}

\section{Question and hypothesis}

Our main and general question is: which organisational behavioural characteristics and individual behavioural characteristics that we discussed above will be associated with the actual use of innovation, i.e., innovation adoption? Based on our discussion of earlier research it is expected that all three organisational behavioural characteristics - workplace innovation, supportive leadership, mindful organising - will affect the actual use of innovation, via the usefulness, ease and subjective norm, that are related to the innovation. Since this analysis is explorative, we do not know exactly what the relations or associations will look like. However, since mindful organising is a new element to include in innovation studies, it is particularly interesting to see what role it plays. Our central hypothesis is that, apart from other organisational elements, mindful organising will positively associate with the perception of innovation, and either directly or indirectly at least partly explain innovation adoption, i.e., the actual use of innovation.

\section{Background of the study}

This article presents the analysis results of the data that was originally gathered for a research project about innovation adoption of employees in the Dutch logistics sector. The purpose of the project was to investigate how the innovative capability of logistics companies could be improved by making better use of the role of employees in the process of absorbing and implementing (existing) innovations. The assumption of that project was that employee engagement is a crucial factor for innovation adoption. Earlier analyses indicate that employee engagement, as an ingredient of workplace innovation, was indeed positively associated with the actual use of innovation (Putnik et al., 2019a; 2019b). Workplace innovations are social and organisational interventions that enable innovation, such as technical innovation, to become embedded and accepted (Oeij, Rus \& Pot, 2017). Innovation, in this research, is understood as a renewal or innovation that is related to a (new) product, a (new) service, a (new) process (work process, production process), organisational renewal 
or improvement, or renewal of personnel deployment. Since workplace innovation has a relation with the structural design of organisations and jobs, mindful organising is pointing to cultural elements related to behaviour and social relations within the workplace.

\section{Research question and hypotheses}

The main question above is operationalised into the following research question and two hypotheses: What is the role of organisational factors in general, including resilience and mindful organising specifically, in perception of innovation and innovation adoption?

Hypothesis 1: Organisational factors (Workplace innovation, Supportive leadership and Mindful organising) have a positive relationship with perception of innovation (Perceived usefulness, Perceived ease of use, Subjective norm).

Hypothesis 2: Perception of innovation (Perceived usefulness, Perceived ease of use, Subjective norm) has a positive relationship with innovation adoption (Actual use of innovation).

\section{Measures and data}

In order to examine our conceptual model, we needed to approach respondents that can overlook the organisation as a whole. For that reason, managers were approached as informants, which implies that 'perceptions of employees' were measured by asking these managers to evaluate the behaviours of their employees.

Electronic surveys were distributed among 335 managers of logistics companies in the Netherlands in 2017. Participants were sampled from three different sources: 1) organisations that took part in the National Employer Survey (Dutch abbreviation WEA) in 2014 and 2016, and had agreed to be approached for future research; 2) organisations approached via the 'General Forwarders and Own Carriers Organisation' (Dutch abbreviation EVO), a network of organisations with logistical or international operators; and 3) managers of transport and logistics organisations known to the researchers from previous research projects. The survey consists of items mostly originating from validated scales. The outcomes of the research are based on these managers' perceptions of employee behaviours. 110 Completed surveys were returned (response rate $=33 \%$ ). Surveys were filled out by directors of organisations, financial or commercial managers, HR managers, or technical managers who answered the questions about the situation within their organisations. Of all participants who filled out the survey, 88 companies (80\%) had implemented an innovation in the past two years. In these companies, $42(38,2 \%)$ introduced a new product, a new service, a new process, an organisational innovation and/or innovative use of personnel, 39 (35,5\%) introduced a new process, an organisational innovation and/or innovative use of personnel, while seven companies (6,3\%) solely introduced a new product and/or a new service. Therefore, the majority of companies that did introduce an innovation had implemented organisational, process renewal and innovative use of personnel measures (i.e., new HR measures) in the past two years. From a theoretical perspective, these types of innovation, if implemented with the engagement of employees, are often understood as exemplifying workplace innovation (Oeij et 
al., 2017). The remaining $22(20 \%)$ had not implemented any innovation, and were dropped from further analyses. The purpose of this study is not to develop a representative overview for the logistics sector, but to test our theoretical assumptions on a sample of logistics firms.

\section{Dependent variable}

Actual use of innovation was measured with a self-constructed item: 'Innovations and renewals are actually used by employees'. Answering categories range from 1 (not at all) to 5 (fully). The variable was dichotomized so that answering categories 1 to 3 were defined as low actual use (value 0 ) and 4 to 5 as high actual use (value 1). This variable refers to the indicator of innovation adoption of employees.

\section{Independent variables}

Perception of the organisational context:

Organisational variables concern the environmental context in which work is carried out. We operationalised this with the following variables: Workplace innovation, Autonomy, Team voice, Supportive leadership and Mindful organising.

Autonomy stands for the degree to which employees can determine the way in which work is carried out. A scale was created (Cronbach $\alpha=0,77$ ) based on four items with answering categories ranging from 1 (not at all) to 5 (fully), originating from the NOVA WEBA survey (Kraan, et al., 2000). An example of an item is: 'Employees can decide themselves about the way in which they carry out their work'.

Team voice concerns the extent to which employees feel free to express their opinions. A scale was created ( $\alpha=0,87$ ) based on four items with answering categories ranging from 1 (not at all) to 5 (fully), originating from a survey of LePine and Van Dyne (2001). An example of one of the items is: 'Every employee freely shares his or her ideas on new projects or changes in the way work is carried out'.

Workplace innovation refers to a combination of autonomy and voice when employees get involved in decision making about innovations. For this purpose, in an earlier analysis (Putnik et al., 2019a) a new variable was constructed from elements of autonomy and team voice to measure the type of work and role of employees. Type of work and role of the employees: Employees in a (logistics) organisation can have a variety of tasks, ranging from managing to operational tasks, depending on their functions or professions. Based on the division of the tasks they carry out, employees can be divided into the following four categories: Employees with primarily preparatory tasks (e.g. planning); employees with primarily supportive tasks (e.g. quality and support, administration); employees with primarily operational tasks (e.g. drivers, operational staff); and employees with primarily managing tasks (e.g. management, supervisors). For every type of employees, engagement of employees in relation to innovation was measured with the following three answering options: 1) employees play no role, 2) a limited number of employees is involved, and 3) all employees are involved.

Degree of involvement in decision making concerning innovation was measured with four items. Per type of employee, degree of involvement in decision making was measured with the following three answering options: 1) they received information about innovation; 2) they were consulted and could provide ideas; 
and 3) they could make choices and take part in decision making. Subsequently, Workplace innovation was calculated based on these four constructs. The figure was coded high (score=1) when the Autonomy scale was high $(>3,0)$; the Team voice scale was high $(>3,0)$, when employees with operational tasks (Role of employees) were all involved in decision making (Degree of involvement=3). All other combinations of these three variables were coded as low workplace innovation $($ score $=0)$.

Supportive leadership concerns the support of the management in terms of time, and space as well as an investment when it comes to innovation. A scale was created (Cronbach $\alpha=0,84$ ) based on three items with five-point answering categories ranging from 1 (not at all) to 5(to a large extent/completely) originating from Kraan et al. (2009) survey. An example of an item is: 'Direct management gives employees time to work out ideas'.

Mindful organising refers to the ability to discuss work errors and mistakes openly and react fast to unexpected changes, pulling on all team members' expertise. A scale was created (Cronbach $\alpha=0,82$ ) based on four items originating from an abbreviated version of the 'safety organising scale' of Vogus and Sutcliffe (2007), which goes back to Weick and Sutcliffe's 'mindfulness organizing scale' (2015, orig. 2001). The answering categories range from 1 (not at all) to 5 (to a very strong extent /completely). The scale includes the following four items: (1) 'Team members have a good "map" of each person's talents and skills'; (2) 'Team members talk about mistakes and ways to learn from them'; (3) 'When errors happen, as team members we discuss how we could have prevented them'; (4) 'When an unexpected situation like a sudden change or project mishap occurs, as team members we rapidly pool our collective expertise to attempt to resolve it.' The last item is the indicator of resilience.

Perception of innovation:

Perception of innovation was measured with three items: 1) Perceived usefulness (item: 'The employees perceive the innovation as useful, for themselves or for their clients', Venkatesh and Davis, 2010); 2) Perceived ease of use (item: 'The ease of use of innovation is high, both for employees themselves and their clients', Davis, 1989), and 3) Subjective norm (item: 'The management communicates regularly to employees about the importance of innovation', Venkatesh et al., 2003; Venkatesh and Davis, 2000). Answering categories for all three items ranged from 1 (not at all) to 5 (fully).

\section{Analyses and Results}

We first performed correlation analyses between variables to rule out multicollinearity (Table 1). Second, organisations with high use of innovation adoption ('high use of innovation') were compared with organisations where innovation adoption was low ('low use of innovation') (Table 2). Finally, in line with the theoretical model, a path analysis based on multiple regressions was carried out in two stages (Figure 2). At the first stage, organisational context (Workplace innovation, Supportive leadership and Mindful organising) was examined with relation to the perception of innovation (Usefulness of innovation, Ease of use of innovation, and Subjective norm concerning innovation). At the second stage, all variables in the model were simultaneously examined with relation to the actual use of innovation as the dependent variable. For these 
Table 1 Means, Standard Deviations and Correlations between the Variables $(n=$ max. 82)

\begin{tabular}{|c|c|c|c|c|c|c|c|c|c|}
\hline & $\Sigma$ & $\theta$ & 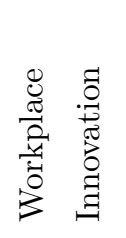 & 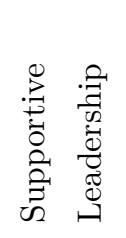 & 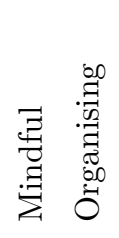 & 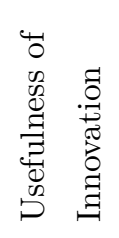 & 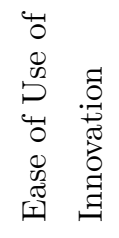 & 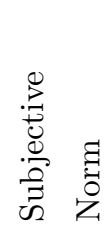 & 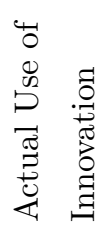 \\
\hline $\begin{array}{l}\text { Workplace } \\
\text { innovation }(0,1)\end{array}$ & 0.11 & 0.31 & 1 & & & & & & \\
\hline $\begin{array}{l}\text { Supportive } \\
\text { leadership (1-5) }\end{array}$ & 3.46 & 0.77 & 0.105 & 1 & & & & & \\
\hline $\begin{array}{l}\text { Mindful } \\
\text { organising (1-5) }\end{array}$ & 3.25 & 0.72 & $.263^{*}$ & $.359^{* *}$ & 1 & & & & \\
\hline $\begin{array}{l}\text { Usefulness of } \\
\text { innovation (1-5) }\end{array}$ & 3.41 & 0.74 & 0.018 & $.374^{* *}$ & $.571^{* *}$ & 1 & & & \\
\hline $\begin{array}{l}\text { Ease of use of } \\
\text { innovation (1-5) }\end{array}$ & 3.56 & 0.61 & $.256^{*}$ & $.263^{*}$ & $.511^{* *}$ & $.486^{* *}$ & 1 & & \\
\hline $\begin{array}{l}\text { Subjective norm } \\
(1-5)\end{array}$ & 3.45 & 0.90 & $.221^{*}$ & $.475^{* *}$ & $.398^{* *}$ & $.282^{*}$ & $.270^{*}$ & 1 & \\
\hline $\begin{array}{l}\text { Actual use of } \\
\text { innovation }(0,1)\end{array}$ & 0.41 & 0.49 & $.348^{* *}$ & $.328^{* *}$ & $.440^{* *}$ & $.499^{* *}$ & $.518^{* *}$ & $.346^{* *}$ & 1 \\
\hline
\end{tabular}

*. Correlation is significant at the 0.05 level (2-tailed).

**. Correlation is significant at the 0.01 level (2-tailed).

analyses, we performed several multiple regression analyses consecutively (see Annex 1). Missing values were deleted in a listwise manner. The results are presented in Figure 2 in the form of a path-diagram (Hayes and Rockwood, 2017). This path analysis was conducted to investigate the process of how different elements of the research model work in practice. Therefore, the first hypothesis is meant to test the perception of organisational factors, and the second one to test the perception of innovation; these perceptions are targeted at different entities, namely the enabling atmosphere of the organisational environment, and the motivation and intention to apply innovation.

Actual use of innovation has a significant positive correlation with all variables in the model (Table 1). The strongest correlations $(>0,5)$ are shown between Mindful organising and Ease of use of innovation, Mindful organising and Usefulness of innovation, Ease of use of innovation and Actual use of innovation. Supported leadership and Subjective norm on average have somewhat lower but still significant correlations with other variables in the model.

Of all organisations that implemented any innovation, only a minority $(40 \%)$ were successful in imple- 


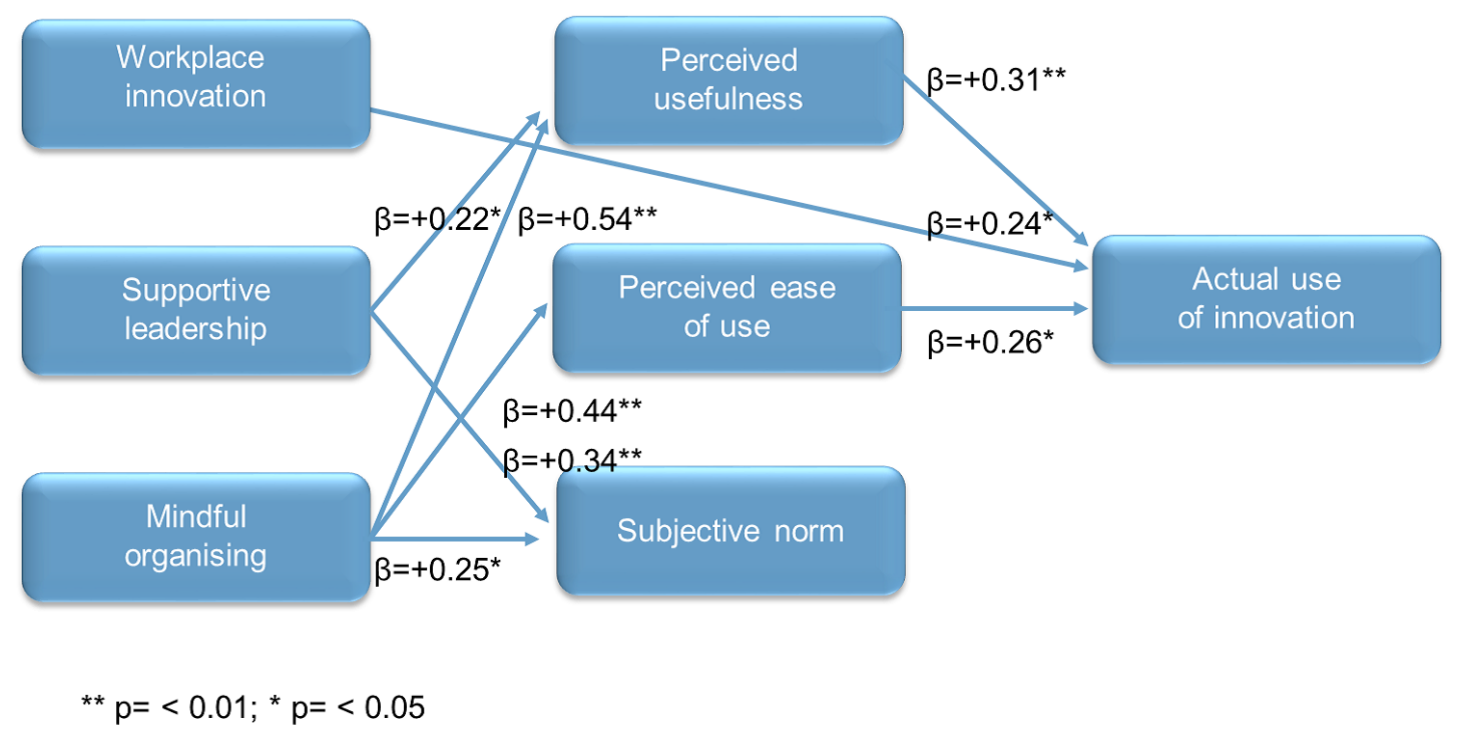

Fig. 3 Path Analysis for the 'Actual Use of Innovation' as Outcome Variable

menting innovation, i.e., their employees actually accepted to work with that innovation. The majority of organisations $(60 \%)$ have a low innovation adoption, which means that not many employees actually accepted to work with the innovation (Graph 1A). Of all organisations, only $11 \%$ can be characterised with a high score on workplace innovation. However, organisations that score high on workplace innovation also show high scores on high-actual use on innovation (Graph 1B). On all organisational aspects, organisations with better performance in Actual use of innovation score significantly higher than organisations with low Actual use of innovation. Organisations that are successfully implementing innovation are characterised by a higher degree of workplace innovation, supportive leadership to employees, and a mindful working climate where unexpected events can be solved in a resilient manner. Such organisations describe innovation itself in more positive terms. Their employees generally perceive innovation as more useful and easier to use. Those are also the organisations where management explains the importance of innovation to the employees (i.e., subjective norm).

The result of path analysis show that Mindful organising is positively related to all three variables of perception of innovation, i.e. Perceived usefulness, Perceived ease of use and Subjective norm. It also suggests that Supportive leadership has a positive relation with Perceived usefulness of innovation and Subjective norm. Workplace innovation, Perceived usefulness and Perceived ease of use have a direct positive relationship with Actual use of innovation (Figure 3, see also Annex 1). The explained variance of the model is $43 \%$ (Adjusted $\mathrm{r} 2=0,38)$. 


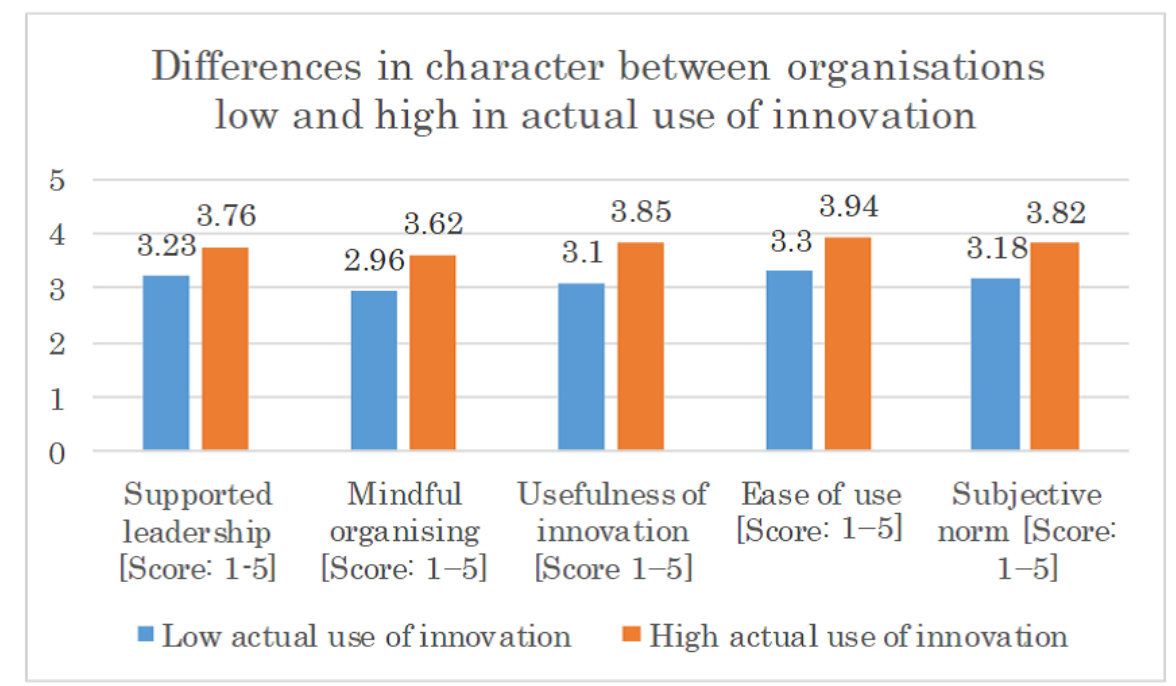

Graph 1A: Mean Scores of Organisations on Leadership, Mindful Organising and Perception of Innovation (Note: All results significantly different $(\mathrm{p}<0,01)$ )

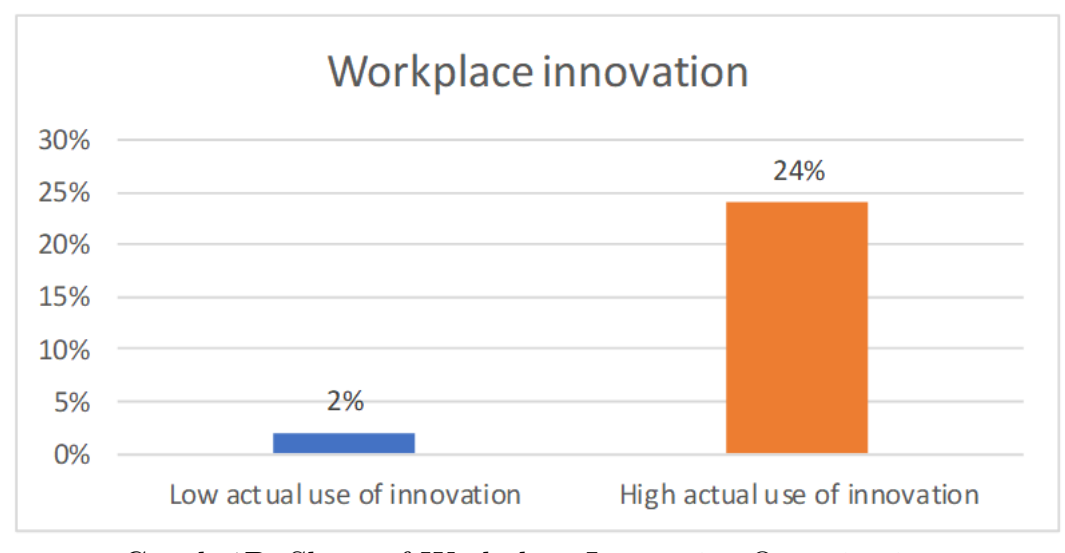

Graph 1B: Share of Workplace Innovative Organisations with Low-high Actual Use of Innovation (11\%)

Graph 1 Mean Scores and Percentages for Organisations with Low Actual Use of Innovation vs High Actual Use of Innovations $(n=82)$

\section{Conclusion}

Concerning the research question - What is the role of organisational factors in general, and resilience and mindful organising specifically, on perception of innovation and innovation adoption? - and the hypotheses we formulated, we can say that the two hypotheses are partly confirmed. The first hypothesis predicts that organisational factors, such as Workplace innovation, Supportive leadership and Mindful organising, have a positive relationship with perception of innovation (Perceived usefulness, Perceived ease of use, Subjective norm). This is confirmed with Mindful organising and partly with Supportive leadership; Workplace 
innovation does not associate with the perception of innovation but directly influences the Actual use of innovation. This implies that mindful organising is a determining factor for employees to perceive innovation as useful, easy to use, and meaningful to others (like managers, who communicate innovation as important to the organisation). It also indicates that meaningfulness of innovation to the employees and the perceived usefulness of an innovation gets a boost from supportive leadership.

The second hypothesis that perception of innovation (Perceived usefulness, Perceived ease of use, Subjective norm) has a positive relationship with innovation adoption (Actual use of innovation), was found to be true for perceived Usefulness and Ease of innovation, apart from the observation that Workplace innovation has a direct effect on Actual use of innovation. Subjective norm does not have an effect on Actual use of innovation.

Organisational factors, such as workplace innovation, supportive leadership and mindful organising, do matter in direct or indirect manners to innovation actually used by employees. This study focuses particularly on the role of mindful organising, including the element of resilience. From this research we conclude that Mindful organising has an indirect influence on the Actual use of innovation, i.e., innovation adoption via perceived Ease of use of innovation.

\section{Limitations and Suggestions for Future Research and Practice}

In this section, we focus on four aspects of our current study that could be improved and provide suggestions for future research.

Firstly, this study is based on validated survey questions that were distributed among managers working in the logistics and transport sector. Future studies could enrich the data by expanding the sample to employees and managers from the same organisations, and carry out multilevel analyses, so we would have nested data. In that way we would be able to account for differences between organisations and examine in more detail the effect of organisational characteristics on innovation adoption of employees. We would also then be able to compare perceptions of managers and employees within the organisations and judge with certainty to what extent the perception of managers matches the perception of their employees. Furthermore, future studies could expand the sample beyond the logistics and transport sector and examine if similar results would be found in other sectors.

Secondly, the current study is of a cross-sectional design. Future studies could collect longitudinal data, as then we would be able to conclude on the causality of the relationships that we see. For example, does workplace innovation cause higher innovation adoption? Or is it true that the two only correlate with each other without actual causal pathway?

Thirdly, in this study, we used a quantitative approach to study innovation adoption. Future studies could supplement the quantitative data with in-depth interviews or focus groups. In this way, we would be able to answer the questions related to the reasons behind the results that we see. For example, what are the mechanisms behind workplace innovation, perceived usefulness of innovation and perceived ease of use of innovation being related to increased actual use of innovation? 
Fourthly, developing the theory a step further it would also benefit from a more sophisticated approach. Better exploration of the importance of mindful organising necessitates multi-level designs and additional qualitative research to understand its mechanisms fully. Team mindfulness, for example, can be seen as an emerging process from individual interactions within teams that results in a shared awareness and attention to present events among team members at the team level (Yu \& Zellmer-Bruhn, 2018; also Gucciardi et al., 2018). Apparently, mindful organising affects three elements of the formation of employees' attitudes towards innovation, but our analyses fail to assess how that works precisely.

Based on the results of this research, we can say that our assumption about the role of mindful organising and resilience on innovation adoption seems to hold. Innovation processes, such as innovation adoption and the implementation of innovation, benefit from insights developed in the world of crisis management and safety science by High Reliability Organisations (HROs). For HROs, it is obvious why they invest in mindful and resilient behavior. It is because people's lives are at stake. Investing in such mindful and resilient behaviour by market organisations, such as in logistics in the Netherlands or in organisations that carry out innovation projects like companies with R\&D departments, may not seem self-evident. Weick and his colleagues $(1999 ; 2015)$, however, contend that each organisation, a non-HRO dependent on handling change and renewal effectively, should be a learning organization, which is capable to deal with unexpected situations mindfully and resiliently. Our findings seem to corroborate such reasoning empirically. Mindful organising can thus be seen as a hallmark of learning organisations. Following Weick and Sutcliffe (2015), we conceptualised resilience as a part of mindful organising, but we realise that there is also extant literature on theorizing resilience and its measurement (Hartmann et al., 2019; also Chapman et al., 2018; Gucciardi et al, 2018).

In addition, we close with a few implications and recommendations for practice. Innovation adoption of process and organisational innovations is complex, as many elements appear to play a role and it may be difficult for managers to decide which elements to focus on. Based on the current findings, and other research (Putnik et al., 2019a, 2019b), we provide advice for managers in logistics who are responsible for implementing innovations. They could: 1) engage employees by supportive leadership and set the example that innovation is relevant to the company and give them (team) voice to express their opinions; 2) stimulate alertness for weak signals and evidence-based decision making and enhance capabilities for resilient problemsolving behaviours of employees, as this has a positive relation with developing a positive attitude towards innovation (i.e., perceived usefulness, perceived ease of use of innovation as well as accepting the subjective norm); 3) ensure that innovation is perceived as useful and as adding to the quality of work or the productivity of employees, as this is clearly related to a higher chance that innovation will actually be used; 4) ensure that innovation is easy to use, because this facilitates the actual use of innovation. Mindful organising, workplace innovation and supportive leadership create an environment conducive to employee engagement, which supports the actual use of innovation (Oeij et al., 2015, 2017; Putnik et al., 2019a). 


\section{Acknowledgement}

This article is an elaborated and extended version of 'The role of mindful organising and resilience in relation to innovation adoption of employees in logistics' (Peter Oeij, Katarina Putnik, \& Steven Dhondt), presented at HTSF 2019, High Tech Small Firms Conference, Session 'Resilience, innovation and entrepreneurship'. University of Twente, 27-28 May, 2019, Enschede, The Netherlands. The study is part of the programme "Accelerator - Knowledge and innovation for a competing logistics sector" and co-financed by NWO, the Dutch Research Council.

\section{References}

Ajzen, I., 1991. "The Theory of Planned Behavior", Organizational Behavior and Human Decision Processes, Vol. 50, No. 2, pp.179-211.

Alliger, G. M., Cerasoli, C. P., Tannenbaum, S. I. and Vessey, W. B., 2015. "Team Resilience: How Teams Flourish under Pressure", Organizational Dynamics, Vol. 4, No. 3, pp. 176-184.

Bagozzi, R. P., Davis, F. D. and Warshaw, P. R., 1992. "Development and Test of a Theory of Technological Learning and Usage", Human Relations, Vol. 45, No. 7, pp. 660-686.

Brummans, B. H. J. M., 2017. Mindful Organizing. In: C. R. Scott, J. R. Barker, T. Kuhn, J. Keyton, P.

K. Turner and L. K. Lewis (eds.), The International Encyclopaedia of Organizational Communication (pp. 1-9). Hoboken, NJ: Wiley-Blackwell. doi:10.1002/9781118955567.wbieoc141.

Burcharth, A., Knudsen, M. P. and Søndergaard, H. A., 2017. "The Role of Employee Autonomy for Open Innovation Performance", Business Process Management Journal, Vol. 23, Issue: 6, pp.1245-1269, https: //doi.org/10.1108/BPMJ-10-2016-0209.

Castellion, G. and Markham, S. K., 2013. "New Product Failure Rates", Journal of Product Innovation Management, Vol. 30, No. 5, pp 976-979, doi:10.1111/j.1540-5885.2012.01009.x.

Chapman, M. T., Lines, R. L., Crane, M., Ducker, K. J., Ntoumanis, N., Peeling, P., Parker, S.K., Quested, E., Temby, F

"Team Resilience: A Scoping Review of Conceptual and Empirical Work", Work 83 Stress, pp. 1-25.

Davis, F. D., 1989. "Perceived Usefulness, Perceived Ease of Use, and User Acceptance of Information Technology", MIS Quarterly, Vol. 13, No. 3, pp. 319-340.

De Clercq, D., 2019. "Getting Creative with Resources: How Resilience, Task Interdependence, and Emotion Sharing Mitigate the Damage of Employee Role Ambiguity", The Journal of Applied Behavioral Science, Vol. 55, No. 3, pp. 369 -391, DOI: 10.1177/0021886319853803.

De Dreu, C. K. D., 2002. "Team Innovation and Team Effectiveness: The Importance of Minority Dissent and Reflexivity", European Journal of Work and Organizational Psychology, Vol. 11, No. 3, pp. 285-298.

De Sitter, L. U., Den Hertog, J. F. and Dankbaar, B., 1997. "From Complex Organizations with Simple Jobs to Simple Organizations with Complex Jobs", Human Relations, Vol. 50, No. 5, pp. 497-534.

De Spiegelaere, S., Van Gyes, G., De Witte, H., Niesen, W. and Van Hootegem, G., 2014. "Job Insecurity, 
Job Autonomy and Innovative Work Behaviour", Creativity and Innovation Management, Vol. 23, No. 3, pp 318-330. DOI:10.1111/caim.12079.

Elbanna, A. and Murray, D., 2009. "Organizing IS Projects for Innovation: A Collective Mindfulness Perspective", AMCIS 2009 Proceedings, The 15th Americas Conference on Information Systems, San Francisco. http://aisel.aisnet.org/amcis2009/276.

Fishbein, M. and Ajzen, I., 2010. Predicting and Changing Behavior: The Reasoned Action Approach. New York: Psychology Press.

Giebels, E., de Reuver, R. S. M., Rispens, S. and Ufkes, E. G., 2016. "The Critical Roles of Task Conflict and Job Autonomy in the Relationship between Proactive Personalities and Innovative Employee Behavior", The Journal of Applied Behavioral Science, Vol. 52, No. 3, pp. 320-341. https://DOI.org/10. $1177 / 0021886316648774$.

Gucciardi, D. F., Crane, M., Ntoumanis, N., Parker, S. K., Thøgersen - Ntoumani, C., Ducker, K. J., Peeling, P., Chapman, "The Emergence of Team Resilience: A Multilevel Conceptual Model of Facilitating Factors", Journal of Occupational and Organizational Psychology, Vol. 91, No. 4, pp. 729-768.

Hartmann, S., Weiss, M., Newman, A. and Hoegl, M., 2019. "Resilience in the Workplace: A Multilevel Review and Synthesis", Applied Psychology, DOI.org/10.1111/apps.12191.

Hoegl, M. And Gemuenden, H. G., 2001. "Teamwork Quality and the Success of Innovative Projects: A Theoretical Concept and Empirical Evidence", Organization Science, Vol. 12, No. 4, pp. 435-449.

Hūlsheger, U. R., Anderson, N. and Salgado, J. F., 2009. "Team-level Predictors of Innovation at Work: A Meta-analysis Spanning Three Decades of Research", Journal of Applied Psychology, Vol. 94, No. 5, pp. 1128-1145.

Karanika-Murray, M., and Oeij, P. R. A., 2017. "The Role of Work and Organizational Psychology for Workplace Innovation: Fortifying Practice", European Work \& Organizational Psychology - In Practice, Vol. 9, No. 1, pp 19-30.

Karasek, R. and Theorell, T., 1990. Healthy Work: Stress, Productivity, and the Reconstruction of Working Life. Basic Books, New York.

Kraan, K. O., Dhondt, S., Houtman, I. L.D., Nelemans, R. And de Vroome, E. M. M., 2000. Handleiding NOVA-WEBA: een vragenlijst om arbeidsorganisatorische knelpunten op te sporen: hernieuwde versie. Hoofddorp: TNO.

Kraan, K., Hooftman, W. and de Jong, T., 2009. Cohortstudie Sociale Innovatie (CSI) 2008-2010: Methodologie en beschrijving eerste meting (2008). Hoofddorp: TNO.

Kremer, H., Villamor, I. and Aguinis, H., 2019. "Innovation Leadership: Best-practice Recommendations for Promoting Employee Creativity, Voice, and Knowledge Sharing", Business Horizons, Vol. 62, pp. 65-74, https://doi.org/10.1016/j.bushor.2018.08.010.

Lawrence, K. A., Lenk, P. and Quinn, R. E., 2009. "Behavioral Complexity in Leadership: The Psychometric Properties of a New Instrument to Measure Behavioral Repertoire", The Leadership Quarterly, Vol. 20, No. 2, pp. 87-102.

LePine, J. A. and Van Dyne, L., 2001. "Voice and Cooperative Behavior as Contrasting Forms of Contex- 
tual Performance: Evidence of Differential Relationships with Big Five Personality Characteristics and Cognitive Ability", Journal of Applied Psychology, Vol. 86, No. 2, pp. 326-336. .

Manpower Group, 2015. Witboek 2015. Wie het weet mag het zeggen: Sociale innovatie in de logistiek. Diemen: ManpowerGroup Nederland.

Mun, Y. Y., Jackson, J. D., Park, J. S. and Probst, J. C., 2006. "Understanding Information Technology Acceptance by Individual Professionals: Toward an Integrative View", Information \& Management, Vol. 43, No. 3, pp. 350-363.

Nusair, N., Ababneh, R. and Kyung Bae, Y., 2012. "The Impact of Transformational Leadership Style on Innovation as Perceived by Public Employees in Jordan", International Journal of Commerce and Management, Vol. 22, No. 3, pp. 182-201.

Oeij, P. R. A., 2018. "The Resilient Innovation Team: A Study of Teams Coping with Critical Incidents during Innovation Projects", in. M. Tynnhammar (ed.), New Waves in Innovation Management Research (pp. 1-17). Vernon Press, Wilmington (DE) \& Malaga (Spain).

Oeij, P., Dhondt, S., Žiauberytė-Jakštienè, R., Corral, A. and Totterdill, P., 2016. "Implementing Workplace Innovation across Europe: Why, How and What?" Economic and Social Changes: Facts, Trends, Forecast, Vol. 5, No. 47, pp. 195-218.

Oeij, P. R. A., Rus, D. and Pot, F. D. Pot (Eds), 2017. Workplace Innovation: Theory, Research and Practice, Series 'Aligning Perspectives on Health, Safety and Well-Being'. Springer: Cham, Switzerland.

Oeij, P. R. A., Žiauberytė-Jakštienè, R., Dhondt, S., Corral, A., Totterdill, P. and Preenen, P. T. Y., 2015. "Workplace Innovation in European Companies", study commissioned by Eurofound. Luxemburg: Office for Official Publications of the European Communities.

Oliver, N., Senturk, M., Calvard, T. S, Potočnik, K. and Tomasella, M., 2017. "Collective Mindfulness, Resilience and Team Performance", Academy of Management Annual Meeting Proceedings, 1:12905, DOI:10.5465/AMBPP.2017.12905abstract.

Putnik, K., Oeij, P., van der Torre, W., de Vroome, E. and Dhondt, S., 2019a. "Innovation Adoption of Employees in Logistics: Individual and Organisational Factors Related to the Actual Use of Innovation", International Journal of Technology Transfer and Commercialisation, Vol. 16, No. 3, pp. 251-267.

Putnik, K., Oeij, P., Dhondt, S., Van der Torre, W., De Vroome, E. and Preenen, P., 2019b. "Innovation Adoption of Employees in the Logistics Sector in the Netherlands: The role of Workplace Innovation", European Journal of Workplace Innovation, Special Issue 'Socio-Technical Systems theory (STS) in manufacturing', 2019, Vol. 4, No. 2, pp. 176-192.

Rogers, E. M., 2003. Diffusion of Innovations (5th ed.). New York: Free Press.

Sarros, J. C., Cooper, B. K. and Santora, J. C., 2008. "Building a Climate for Innovation through Transformational Leadership and Organizational Culture", Journal of Leadership \& Organizational Studies, Vol. 15, No. 2, pp. 145-158.

Sullivan, B. N. \& Yang, X., 2016. "Can Mindful Firms be Innovative? Differentiated Impact of Organizational Mindfulness on Innovation", Academy of Management Proceedings 2016:1, https://doi.org/10. 5465/ambpp.2016.12802abstract. 
Sutcliffe, K. M., Vogus, T. J. and Dane, E., 2016. "Mindfulness in Organizations: A Cross-level Review", Annual Review of Organizational Psychology and Organizational Behavior, Vol. 3, pp. 55-81.

Taherdoost, H., 2018. "A Review of Technology Acceptance and Adoption Models and Theories", Procedia Manufacturing, Vol. 22, pp. 960-967, doi.org/10.1016/j.promfg.2018.03.137.

Theurer, C. P., Tumasjan, A. and Welpe, I. M., 2018. "Contextual Work Design and Employee Innovative Work Behavior: When Does Autonomy Matter?" PloS one, Vol. 13, No. 10, e0204089. doi:10.1371/journal.pone.0204089.

Todt, G., Weiss, M. and Hoegl, M., 2019. "Leading through Innovation Project Setbacks: How Authentic Leaders Keep Their Innovators Resilient", Project Management Journal, Vol. 50, No. 4, pp. 1-9. DOI: $10.1177 / 8756972819853124$.

Tolk, J. N., Cantu, J. and Beruvides, M., 2015. "High Reliability Organization Research: A Literature Review for Health Care", Engineering Management Journal, Vol. 27, No. 4, pp. 218-237.

Top Sector Logistics, 2020. Retrieved on Jan. 29, 2020 from https://www.holland.com/global/meetings/ holland-in-congres/logistics/top-sector-logistics.htm

Tornikoski, E. and Maalaoui, A., 2019. "Critical Reflections - The Theory of Planned Behaviour: An Interview with Icek Ajzen with Implications for Entrepreneurship Research", International Small Business Journal: Researching Entrepreneurship, Vol. 37, No. 5, pp. 536-550.

Totterdill, P. and Exton, R., 2017. "Creating the Bottom-up Organisation from the Top: Leaders as Enablers of Workplace innovation", in P. R. A. Oeij, D. Rus, F. D. Pot (Eds.), Workplace Innovation: Theory, Research and Practice (pp. 189-207). Cham: Springer.

Venkatesh, V. and Davis, F. D., 2000. "A Theoretical Extension of the Technology Acceptance Model: Four Longitudinal Field Studies", Management Science, Vol. 46, No. 2, pp. 186-204.

Vogus, T. J. and Sutcliffe, K. M., 2007. "The Safety Organizing Scale: Development and Validation of a Behavioral Measure of Safety Culture in Hospital Nursing Units", Medical Care, Vol. 45, No. 1, pp. 46-54.

Vogus, T. J. and Welbourne, T. M., 2003. "Structuring for High Reliability: HR Practices and Mindful Processes in Reliability - Seeking organizations", Journal of Organizational Be $\neg$ havior, Vol. 24, No. 7, pp. 877-903.

Weick, K. E. and Sutcliffe, K. M., 2015. Managing the Unexpected: Sustained Performance in a Complex World (3d ed.; 1st ed. 2001). Chichester: Wiley.

Weick, K. E., Sutcliffe, K. M. and Obstfeld, D., 1999. "Organizing for High Reliability: Processes of Collective Mindfulness", in R. S. Sutton \& B. M. Staw (Eds.), Research in Organizational Behavior, Volume 21 (pp. 81-123). Stanford: Jai Press.

Wisdom, J. P., Chor, K. H. B., Hoagwood, K. E. and Horwitz, S. M., 2014. "Innovation Adoption: A Review of Theories and Constructs", Administration and Policy in Mental Health and Mental Health Services Research, Vol. 41, No. 4, pp.480-502.

Witboek 'Sociale innovatie in de logistiek', 2015. Manpower Group. Sine loco. (White paper Workplace innovation in logistics). 
Ye, Q., Wang, D. and Guo, W., 2019. "Inclusive Leadership and Team Innovation: The Role of Team Voice and Performance Pressure", European Management Journal, https://doi.org/10.1016/j.emj.2019. 01.006 .

Yu, L. and Zellmer-Bruhn, M., 2018. "Introducing Team Mindfulness and Considering Its Safeguard Role against Conflict Transformation and Social Undermining", Academy of Management Journal, Vol. 61, No. 1, pp. 324-347.

Yukl, G., 2012. "Effective Leadership Behavior: What We Know and What Questions Need More Attention", The Academy of Management Perspectives, Vol. 26, No. 4, pp. 66-85.

Hayes A. F., \& Rockwood N. J. (2017). "Regression-based statistical mediation and moderation analysis in clinical research: Observations, recommendations, and implementation", Behaviour Research and Therapy, Vol. 98, pp. 39-57. 


\section{Annex 1 Path Analysis - detailed results}

STAGE 1 describes linear regressions between three variables on the left side of our model (Workplace Innovation, Supportive leadership and Mindful organising) in relation to the three outcome variables Usefulness of innovation, Ease of use of innovation and Subjective norm.

Table 1 Linear Regression for Usefulness of Innovation as Outcome Variable

\begin{tabular}{|l|l|l|l|l|}
\hline \multirow{2}{*}{ Independent variables } & \multicolumn{2}{|c|}{ Unstandardised coefficients } & \multicolumn{1}{c|}{$\begin{array}{c}\text { Standardised } \\
\text { coefficients }\end{array}$} & \\
\cline { 2 - 5 } & $B$ & $S E$ & Beta & Significance \\
\hline Workplace innovation & -.345 & .216 & -.148 & .115 \\
\hline Supportive leadership & .211 & .090 & .221 & .022 \\
\hline Mindful organising & .560 & .101 & .542 & .000 \\
\hline
\end{tabular}

Table 2 Linear Regression for Ease of Use of Innovation as Outcome Variable

\begin{tabular}{|l|l|l|l|l|}
\hline \multirow{2}{*}{ Independent variables } & \multicolumn{2}{|c|}{ Unstandardised coefficients } & $\begin{array}{c}\text { Standardised } \\
\text { coefficients }\end{array}$ & \\
\cline { 2 - 5 } & $B$ & $S E$ & Beta & Significance \\
\hline Workplace innovation & .248 & .193 & .129 & .204 \\
\hline Supportive leadership & .089 & .081 & .112 & .275 \\
\hline Mindful organising & .378 & .090 & .442 & .000 \\
\hline
\end{tabular}

Table 3 Linear Regression for Subjective Norm as Outcome Variable

\begin{tabular}{|l|l|l|l|l|}
\hline \multirow{2}{*}{ Independent variables } & \multicolumn{2}{|c|}{ Unstandardised coefficients } & \multicolumn{1}{c|}{$\begin{array}{c}\text { Standardised } \\
\text { coefficients }\end{array}$} & \\
\cline { 2 - 5 } & $B$ & $S E$ & Beta & Significance \\
\hline Workplace innovation & .343 & .287 & .121 & .236 \\
\hline Supportive leadership & .395 & .120 & .341 & .001 \\
\hline Mindful organising & .312 & .133 & .249 & .022 \\
\hline
\end{tabular}


STAGE 2 describes a linear regression model between all elements in the model in relation to the Actual use of innovation as outcome variable.

Table 4 Linear regression for Actual use of innovation as outcome variablee

\begin{tabular}{|l|l|l|l|l|}
\hline \multirow{2}{*}{ Independent variables } & \multicolumn{2}{|c|}{ Unstandardised coefficients } & \multicolumn{1}{|c|}{$\begin{array}{c}\text { Standardised } \\
\text { coefficients }\end{array}$} & \\
\cline { 2 - 5 } & $B$ & SE & Beta & Significance \\
\hline Workplace innovation & .381 & .149 & .244 & .013 \\
\hline Supportive leadership & .044 & .065 & .069 & .505 \\
\hline Mindful organising & .001 & .083 & .001 & .994 \\
\hline $\begin{array}{l}\text { Usefulness of innova- } \\
\text { tion }\end{array}$ & .208 & .079 & .311 & .010 \\
\hline Ease of use & .209 & .088 & .259 & .021 \\
\hline Subjective norm & .057 & .057 & .103 & .324 \\
\hline
\end{tabular}

